\title{
FINANCIAL BEHAVIOR OF UNITED TERRITORIAL COMMUNITIES IN THE CONDITIONS OF DECENTRALIZATION REFORM IN UKRAINE
}

\author{
VIKTOR MELNYK, ROMAN SHCHUR, OKSANA TSIUPA
}

\begin{abstract}
The article deals with the study of amalgamated territorial communities functioning peculiarities during the decentralization in Ukraine. It contains substantiation of the territorial community's financial behavior as a basis for efficient administrative and financial decisions, as well as a study of the character and model of this behavior. The research of the models and peculiarities of amalgamated territorial communities' financial behavior allows assessment and forecast of their social and economic development vectors; establishing the grounds for subsidies and opportunities for the increase of financial solvency regarding the formation of their expenses and performance of functions and assignments, laid upon them. The results of the research have emphasized the need for further scientific studies of behavioral aspects of the amalgamated territorial communities' financial resources forming, as well as substantiation of their financial decisions for the attraction of additional proceeds. Active implementation of decentralization reform in Ukraine has started only in 2014 with creation of amalgamated territorial communities. The authors have researched the essence of the amalgamated territorial community's financial behavior, being the basis for the establishment of its financial solvency, sustainability, as well as social and economic development. The study found that the main factor influencing the financial behavior of amalgamated territorial communities in Ukraine in terms of the priority of their budget expenditures and investment activities is the size of the community (characterized by area and population). The authors also proved that the key motives for the financial behavior of amalgamated territorial communities in matters of priority of budget expenditures and investment activities are the following: increasing their own revenues and increasing the financial independence of local governments. This actualizes the search for their own ways to strengthen financial capacity and prepare attractive offers to investors and increase the number of jobs, as well as further unification of small local communities.
\end{abstract}

Keywords: budget decentralization, amalgamated territorial community, financial behavior of amalgamated territorial community, own income, subsidy level.

JEL Classification: H 72, R 51. 


\section{INTRODUCTION}

In the current context of the reform of local self-governance in Ukraine, the issue of decentralization becomes particularly relevant, since it is one of the basic conditions for the independence and effective functioning of local self-government bodies.

Given that the vast majority of village, town and city budgets of cities of rayon significance were deeply subsidized, depriving territorial communities of the opportunity to carry out the necessary expenditures for socio-economic development, the task was to combine such administrative and territorial units into united territorial communities. It is important, however, to achieve the financial capacity of the community, which consists in the ability to independently, through the relevant local authorities, at the expense of their own resources, to resolve issues of local importance in the interests of the inhabitants, providing the appropriate level of education, culture, health care, social protection, housing and communal services, etc.

The accumulation and use of the own financial resources of the united territorial communities involve the attraction of funds from different sources and their distribution in directions according to needs. The multivariateness of the relevant decisions and the work on their implementation forms the financial behavior of the community.

\section{Literature ReVieW, Generalization of MAin Statements}

The question of financial behavior was devoted to a sufficiently large number of works of domestic and foreign authors. But all the developments concerned financial the behavior of households. J. Keynes [1], F. Modigliani [2], J. Tobin [3], M. Hardy [4], W. Sharpe [5], T. Schultz and others, made a significant contribution to the formation of the theory of household finance.

Theoretical aspects of the financial behavior of the population, including in terms of the effectiveness of decision-making, are defined in the studies of Ukrainian authors T. Kizimi [6], V. Fedosov, I. Lomachinskaya, O. Dragan, V. Tropin, I. Chugunov, and others.

However, as mentioned above, the most frequently mentioned studies concerned financial decisions of citizens and households; but their associations, formed on a territorial basis, taking into account the place of residence, in fact, in this aspect are only beginning to be studied.

As for the term "financial behavior", he entered the scientific circulation primarily with regard to the definition of certain types of activity of the population (households) in the financial market. Therefore, the most widespread definition of it is the representation as a form of activity of individuals and separate social groups in the financial market, related to the redistribution, in particular, the investment, of cash resources [7]. Some authors branch out from its characteristics through the prism of investment, treating it as a system of actions of individuals and social groups in the financial market for the purpose of the maximum profitable use of their available monetary resources [8]. Although activity in the financial market is predominantly of an investment nature, it is possible to maximize profits through various short-term or one-time speculative operations, etc. Beyond the boundaries of the financial market, the financial behavior of the population is considered, explaining its essence as the use of cash outside of current consumption [9].

A wider understanding of the essence of financial behavior of individuals and households belongs to the development of Ukrainian authors T. Kizima, I. Yakushik, I. Lomachinskaya and O. Dragan, as well as one of the co-authors of this publication [10], which, together with the previous three, conducted the relevant research.

In particular, T. Kizima submits the corresponding definition "as the activity of households related to the allocation and redistribution of cash resources, resulting in the formation of appropriate monetary funds (individual and common funds of consumption, a reserve fund, savings fund, etc.) and their use for certain purposes" [6]. As the author notes, there are also such aspects of the financial activity of citizens as consumer, fiscal, charitable, etc. In favor of this view, existing developments in the field of the economic and sociological analysis indicate that financial behavior is "a variety of external 
manifestations of the use of money aimed at achieving different goals in the context of formal and informal rules and social relations" [11].

In a collective monograph with the participation of one of the co-authors of this article V. Melnyk and I. Yakushik, I. Lomachinskaya, O. Dragan under the financial behavior of households, they consider an even broader range of actions, not limited to the distribution and redistribution of those available to these entities cash resources, but also including the formation of their income. The authors point out that "the financial behavior of households should be understood as individual decisions regarding the formation of cash incomes, their distribution and use in order to meet individual social and economic interests" [10].

Analyzing given definitions, it should be noted that the following essential aspects are clearly perceived:

- financial behavior as a certain set of actions, decisions in modern socio-economic conditions are typical for individuals, households, social groups, and therefore can be considered for associations of citizens formed by territorial or some other feature in order to solve common problems or achieve a common goal or a specified set of goals;

- the interpretation of financial behavior in the broad sense implies actions and decisions on the formation of cash, their distribution and use in order to satisfy the interests of the entity demonstrating this behavior, achieve certain economic and social goals.

\section{DiscUSSION}

Since the united territorial community is a voluntary association of inhabitants of different settlements in one administrative center, it is a social group formed by a set of individuals according to the criterion of the place of residence. Consequently, according to the selected essential aspects of financial behavior, the united territorial community can also be considered as the subject of its formation and implementation. Taking into account the specifics of the finances of the mentioned administrative-territorial units, the financial behavior of the united territorial community is the decision taken by the residents jointly with regard to the formation of cash incomes, their distribution and use in order to meet the socio-economic interests of the community and its members, as well as a set of administrative actions on the implementation of these decisions.

Analyzing the financial practice of the united territorial communities, one can notice a large similarity of the types of financial behavior with households. This can be explained by the fact that they consist of a relatively small number of households, which are united administratively and territorially. Although sources of cash-flow and spending patterns differ from households, management behavior combines psychological and mental approaches of individuals and separate methods developed by the state.

Based on this, depending on the attitude towards the common goals of the community and the use of methods for achieving them, the following models of financial behavior are distinguished: passiveconsumer; consumer-saving; active-investment.

In the first model, the community seeks to solve current problems mainly by concentrating available resources on their financing. Search for additional resources is not carried out; in case of the lack of funds, hopes for transfers from other budgets are relied upon. At the same time, the community has: assets that, due to underestimation, bring in insufficient incomes in comparison with the potentially possible; unused assets in the economic circulation, the opportunities of which nobody cares; illiquid assets for which there is neither strategy for increasing their public and market value, nor options for reducing their conditional fixed costs associated with their existence.

In the second model, the community is more diversifying its financial behavior, but mainly on cost issues. It tries to save money, directing them to a wider range of solvable problems. At the same time, assimilation of funds takes place at a rapid pace, securing from possible their depreciation due to changes in the value of goods and services during the budget year. However, the diversification of 
sources of funds does not occur or it's quite sluggish, especially with respect to incomes from underestimated property objects, etc.

In the third model, financial behavior is maximally diversified. Active strategies for attracting revenues from all possible sources (including grants) and from maximizing the use of all available assets are being developed, the use of funds is economical, cash-flow operations for their passive deposit storage are not considered, preferring investment in infrastructure and other objects.

Also, the models of financial behavior of the united territorial communities may vary depending on the nature of the municipal management. In this case, it is necessary to point out the following types of financial behavior: rational; traditionally patriarchal; affective-irrational.

For the first type, the financial management of the united territorial community is based on clear planning, analytical approaches and the use of reasonable cost-saving regimes. According to the second type, stereotypes of previous generations, ethnic and religious peculiarities of the community, the use of which in today's conditions is economically unjustified and incapable of causing social development effects, is used to a large extent in developing strategies for the accumulation of funds and their spending patterns. In the third type, financial decisions are made situationally, the laws of financial activity are ignored.

In general, in today's domestic conditions, as part of the formation of revenue united territorial communities plan tax- and non-tax revenues to the budget, revenues of utility companies, etc. The procedure for such actions is clearly regulated by the current legislation of Ukraine (especially with regard to the establishment of local taxes and fees, the formation of intergovernmental transfers), and the lost opportunities (in terms of income from disposal of property and commercial activity of utility companies) are monitored by the State Audit Office and measures for their renewal are being developed (albeit with a break in time that is inevitable for retrospective control). In the case of the use of funds, there is a bigger opportunity to take the initiative, as decentralization processes involve the gradual expansion of the capacity of the united territorial communities to determine the priority of a number of budgetary expenditures and investment activity. The use of funds in today's conditions for them is a bigger stimulus than the accumulation because it involves the choice of perspective directions, forms, the order of financing. Therefore, this particular issue was chosen by us as an object of analysis in this publication.

It is important to determine which key factors influence the financial behavior of the united territorial communities in Ukraine in terms of the priority of their budget expenditures and investment activity. To do this, we will analyze the indicators of the area and population of these communities, their own revenues (since it determines the possibility of financing expenditures, especially investment), the level of dotations (the share of dotations in income) and capital expenditures (Table 1). To do this, we use the data of the Financial Monitoring Group of the Central Office of Reforms under the Ministry of Regional Development, Construction and Housing and Communal Services of Ukraine about 665 united territorial communities in 2018.

\begin{tabular}{|c|c|c|c|c|c|}
\hline № & $\begin{array}{c}\text { Population } \\
\text { (thousands of } \\
\text { people) }\end{array}$ & $\begin{array}{c}\text { Area } \\
\text { (square km) }\end{array}$ & $\begin{array}{c}\text { Average own } \\
\text { revenue of UTC } \\
\text { (mln. UAH) }\end{array}$ & $\begin{array}{c}\text { Maximum level of } \\
\text { dotations (\%) }\end{array}$ & $\begin{array}{c}\text { Average capital } \\
\text { expenditures of } \\
\text { UTC } \\
\text { (mln. UAH) }\end{array}$ \\
\hline 1 & More than 15 & $35-2011$ & 75,5 & 47,6 & 22,4 \\
\hline 2 & $10-15$ & $34-1004$ & 47,0 & 54,8 & 15,5 \\
\hline 3 & $5-10$ & $32-927$ & 26,1 & 57,9 & 9,5 \\
\hline 4 & Up to 5 & $29-557$ & 14,2 & 60,3 & 4,8 \\
\hline
\end{tabular}

Tab. 1. Factors of financial behavior of the united territorial communities of Ukraine in terms of priority of their budget expenditures and investment activity. Source: developed by the authors. 
To monitor the dependence of income indicators, dotations and capital expenditures on the size of the united territorial community, we will construct corresponding schedules, the inclination of which will show the nature of such dependence.

Thus, for the reasons given in Figure 1, it can be concluded that with the increase in the size of the united territorial community, as a rule, its own revenues and capital expenditures increase, and the level of dotations decreases. That is, the financial behavior in terms of the sources of financing of expenditures and investment activity at the current stage in Ukraine is determined by the scale of the mentioned entities. The largest communities - with a population of over 15 thousand people - have the opportunity to receive higher own revenues and, accordingly, are least dependent on dotations from the state budget of Ukraine. Their capital expenditures are the highest. The reverse situation is observed in communities with a small population and area. «Such communities do not have sufficient labour potential for their development and good governance. An exception is made by separate communities, in the territories of which there are budget-setting enterprises and powerful enterprises of the real sector of the economy» [12].

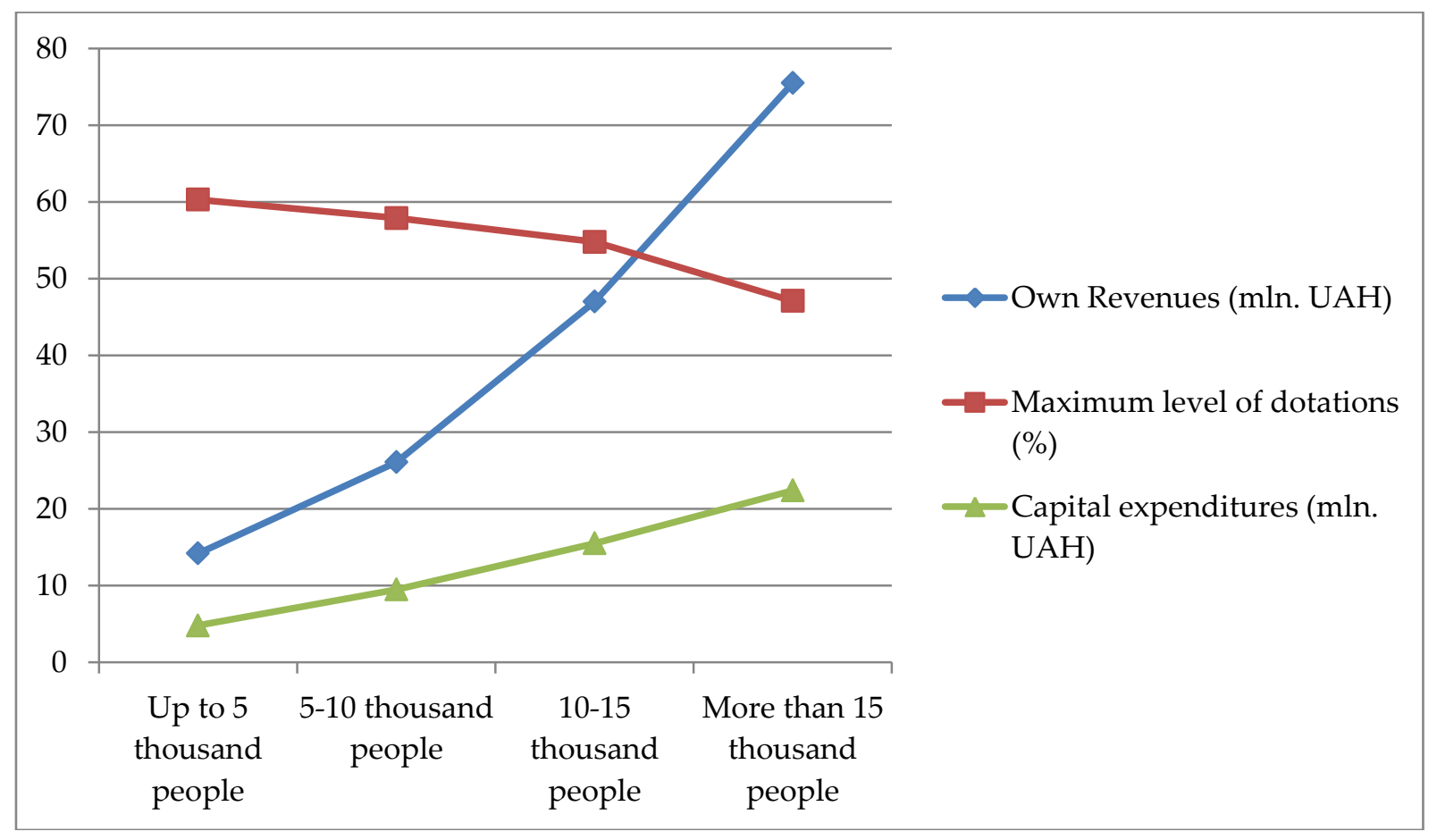

Fig. 1. Change in own income, level of dotations and capital expenditures depending on the size of the united territorial communities. Source: developed by the authors.

Proceeding from the above, the preconditions for the formation of optimal financial behavior of the united territorial communities in matters of priority of budget expenditures and investment activity are:

1. Increase in own revenues (as sources of financing of expenditures, including investment) and increase of financial independence of local self-government bodies, which in turn actualize:

- search for their own paths to strengthen financial potential;

- preparation of attractive proposals for investors and increasing the number of jobs.

2. The further consolidation of small territorial communities and the formation of communities with larger areas and population, which, even in the face of insufficient financial potential, will open up opportunities for:

- optimization of the territorial structure of local self-government bodies;

- improvement the management efficiency and directing the money saved on it to other priority areas of financing; 
- improvement of investment attractiveness due to the concentration of a large volume of labour and land resources in one subject.

Also, the analysis of the practice of functioning of the united territorial communities in Ukraine testifies to the need to implement a number of organizational measures designed to optimize their financial behavior in matters of priority of budget expenditures and investment activity.

First of all, it concerns the organization of strategic documents. In particular, the development goals contained in them are often indicated formally and do not correlate with each other and with the expenditures of the local budget. Without a strategic managerial vision, it seems problematic to expand the existing or attract additional sources of revenue, optimize costs and dispose of community assets.

In addition, the realization of strategic directions of development is impossible without building the trust of households in local self-government bodies. In this context, it is important to ensure public participation in public hearings and discussions, including budget issues, engage civic activists in decision-making processes and ensure the informational openness of the leadership of the united territorial communities (in spite of existing personal political risks).

An important part of the formation of financial behavior of the united territorial communities is the optimization of the current budget expenditures, which will increase investment opportunities. In particular, the high costs of education and medicine in many communities are not dictated by the goals of social development but are caused by a non-optimal network of institutions. Therefore, the continuation of measures for its optimization will enable the redistribution of the local budget in favor of capital expenditures and development costs [13].

In this context, also need to be resolved: the issues of procurement activity of united territorial communities, the realization of which in a number of examples demonstrates violation of the current legislation and conflict of interests; the issue of improving the management of community assets, primarily on the basis of inventory and control over the use of land and other property. This, in turn, necessitates the construction of a system of internal control, including the introduction of mechanisms for public audit.

It should also be noted that local councils of united territorial communities have the right to borrow (from both domestic and international financial organizations) to finance their expenditures, which can not be financed from existing sources of funds available at the moment. That is, in the long run, they can become important participants in the financial market, and their financial behavior will significantly affect the redistribution of investment resources. Borrowed funds will be directed to the development budget in order to spend on implementation of investment projects in the field of communal infrastructure, resource conservation, construction and renewal of long-term objects of strategic importance, used by local councils to fulfill tasks for satisfying the interests of the population.

There are a number of restrictions on the execution of local borrowings, which have an impact on the financial behavior of the united territorial communities in this regard. In particular:

- the amounts and conditions of local borrowing, as well as the provision of local guarantees, must be agreed with the Ministry of Finance of Ukraine. Obviously, this is due to several objective reasons - the lack of local analysts; allocation of transfers from the state budget to finance the expenses of the united territorial communities, which necessitates control over their financial behavior and the policy of formation and spending of budget funds;

- the cost of servicing local debts cannot exceed $10 \%$ of the general fund's expenditures of the local budget;

- the borrowing in the form of bonds under the current legislation is allowed only to urban communities.

In the process of the formation of the financial behavior of the united territorial community, it should be taken into account that there are several ways to implement local borrowing, that is, the latter can exist in the following forms:

- loans from banks and other lending institutions and financial companies (as a rule, these loans can be used in the financing of small amounts of money and short-term projects, which is conditioned, 
among other things, by the unreadiness of commercial financial institutions to lend to predominantly subsidized municipal self-government bodies);

- bond loans (for the urban communities that can issue municipal bonds in paper or electronic form) (as a rule, are intended to finance long-term municipal investments: development of electricity supply, water supply and sewerage systems, transport networks, construction of educational, health care, culture or sports institutions, etc. Interest rates and maturity of the bonds are determined by market conditions);

- mutual loans of local self-government bodies (intended to cover temporary cash disruptions);

- medium-term loans from a single treasury account (treasury loans) (appointment is similar to the previous one).

Recently, thanks to the integration of Ukraine into the EU, a new form of local borrowing - loans from international financial institutions - appears. They can be obtained directly by united territorial communities or through the mediation of a domestic bank. The scope and conditions for the implementation of such borrowings are also subject to approval by the Ministry of Finance of Ukraine. At the same time, if the Ministry of Finance has not made any decision within a month from the date of submission of the documents, the loan is considered as agreed.

Local debt servicing may sometimes be crucial for taking into account the financial behavior of the united territorial communities. The standard option is servicing through the budget. However, if the funds were spent on creating a profitable object, debt servicing could be carried out through the mechanism of state securitization of cash flows, in which profits from an object accumulate on a special account and repayment of a loan is carried out. Upon full payment, the proceeds are directed to the community accounts. As a rule, such a mechanism is applied to a bond loan [14].

An important direction in the formation of the financial behavior of local governments of the united territorial communities is the providing of grants. They provide a certain impulse for the start and development of investment activities. The placement of grants from international institutions, interstate organizations, government donors of foreign states, public, private, corporate donors, charitable foundations and public organizations (including domestic ones) is ongoing. The task of community leaders is to monitor the announcement of competitions, the well-timed preparation of the necessary documents and the providing of participation. This allows to solve a number of socio-economic issues, such as: improvement of settlements, territories of general use and separate social objects; development of business (for example, agricultural, small and medium) on the territory of a united territorial community; development of local transport infrastructure; creation or restoration of ecological infrastructure; restoration of water resources management infrastructure; promotion of sustainable types of transport that do not produce or produce a low negative impact on the environment; improvement of providing of communal and domestic services; development of marketing infrastructure; introduction of energy-efficient technologies in the territory of a united territorial community (for example, development of "green" energy, production of alternative fuels); introduction of projects to improve the disposal of community property (for example, lease programs that increase the income from lease of community land); purchase of new equipment; introduction of new information technologies; development of information and communication solutions; designing of objects and development of technical documentation; carrying out of engineering researches; involvement of experts, consultants; expert support for creating a supportive business environment in the community; carrying out of studies; improvement of social infrastructure; realization of educational projects aimed at development of certain competences and skills of children and adults; support of the system of primary health care; introduction of social projects aimed at supporting vulnerable groups of the population; improvement of housing sector management; preventing unregulated labor migration by creating new jobs; development of youth, public sector, volunteering, social and public initiatives; promotion of cooperation and mutual understanding between youth; promotion of mutual assistance; promotion of information exchange; information and public events; etc [15].

Unfortunately, there is no consolidated information on the amount of received and assimilated grants by united territorial communities in Ukraine, so it is not possible to carry out a quantitative 
analysis of the financial behavior of the communities on this issue. It can only be argued that due to the lack of professional education of management personnel, a number of communities do not use these capabilities, the relevant information is not monitored and documents for participation in the competitions are not provided. Although the All-Ukrainian Association of Town and Village Councils conduct relevant information events and disseminates the necessary information. The Association maintains on its website a special web-page "Grants», which concentrates all the announcements on grant competitions and terms of participation in them. The same is done by regional state administrations on their sites, providing information on grants available on the territory of the region.

The implementation of important investment projects also involves the pooling of resources of various united territorial communities based on the use of the mechanism of inter-municipal cooperation. It is advisable to use it in cases where one of the local problems is common and at the same time goes beyond the powers and capabilities of each individual community. Then there may be entered cooperation agreements, joint coordination bodies or joint utilities formed, the task of which may be the implementation of one project or long-term cooperation. Today, such cooperation is not widespread and is widely practiced. And the reasons are not only in the lack of funds (exactly this problem is solved by uniting efforts) but also in the absence of sufficient knowledge and experience from local authorities and specialists of municipalities.

As a whole, the evidence shows that the task of optimizing the financial behavior of the united territorial communities in terms of priority of budget expenditures and investment activity actualizes the problem of raising the level of financial literacy and financial culture of the population and the leadership of local self-government bodies. Receiving them at least basic financial knowledge and skills would increase their competence and significantly increase the efficiency of financial decisions at the local level. It should be noted that Ukrainian universities and public organizations have prepared training materials for local government officials on the planning and management of the financial resources of the territorial community, the formation of budgets of territorial communities, and the specifics of managing the development of united territorial communities, etc. They serve to solve this problem by revealing at the popular level various aspects of the formation and use of financial resources of territorial communities, improvement of expenditures of local budgets, opportunities of local self-government in forming their incomes, solving problems of territorial communities through transfer policy, improving the financial condition of communal enterprises and participation of local authorities in their management, use of land resources and other types of property, strengthening financial control at the local level, attracting potential sources of funds for territorial communities, and eliminating corruption in the area of the formation and use of financial resources of local selfgovernment bodies. However, the activity of their use so far leaves much to be desired. Although the motives for financial behavior are determined primarily by the needs of the united territorial communities in terms of consumption and investment, it reflects both the financial interests of the community and its members and socially significant requirements, but a complete understanding of these requirements and almost professional judgment of the interests and means of balancing them will help to get closer to meet the needs.

\section{CONCLUSIONS}

Consequently, it should be noted that the united territorial communities can also be considered as subjects of the formation and implementation of financial behavior, which in essence represents a decision taken by the residents jointly in relation to the formation of cash incomes, their distribution and use in order to meet socio-economic interests of the community and its members, as well as a set of administrative actions for the implementation of these decisions.

Models of financial behavior of the united territorial communities are distinguished depending on the attitude towards the common goals of the community and the use of the methods of their achievement (passive-consumer, consumer-saving and active-investment), as well as depending on the nature of the municipal government (rational, traditionally patriarchal, affective - irrational). The scale 
of the community (which is characterized by indicators of the area and population size) is a major factor affecting the financial behavior of the united territorial communities in Ukraine in terms of the priority of their budget expenditures and investment activity. It has a substantial effect on the volume of own revenues, which form the possibility of financing costs (especially investment), the level of dotations and capital expenditures. As the size of the united territorial community grows, as a rule, its own revenues and capital expenditures increase, and the level of dotations decreases.

Therefore, the main precondition for the formation of optimal financial behavior of the united territorial communities in terms of priority of budget expenditures and investment activity is the further consolidation of small communities and the formation of communities with larger areas and populations.

\section{REFERENCES}

[1] Keynes J.M. The general theory of employment, interest and money. Macmillan, London, 1973.

[2] Modigliani F., Brumberg R. Utility analysis and the consumption function: an interpretation of crosssection data. In: Kurihara K. (Ed.) Post Keynesian Economics. New Brunswick: Rutgers University Press, New York, 1954, 388-436.

[3] Tobyn Dzh. Monetary policy and economic growth. Trans. from Eng. Moskow, 2010. (in Russian)

[4] Hardy M., et. al. Tax increment financing, 2016. Available at: https://www.coalitionforalivablecityvt. org/wp-content/uploads/2016/10/Tax-increment-financing.pdf

[5] Sharpe W.F. Mutual Fund Performance. Journal of Business, 39 (1) (1966), 119-138.

[6] Kizima T. Financial behavior of households: essence, classification, factors of influence. The world of finance (4) (2011), 19-26. (in Ukrainian)

[7] Efremenko T. Financial behavior of the population of Ukraine. Sociology: theory, methods, marketing, 2 (2002), 165-175. (in Ukrainian)

[8] Verkhovin V.I. Economic Sociology. Ed. by V. Demin. IMT, M., 1998. (in Russian)

[9] Tapilina V., Bogomolova T. Financial behavior of Russian households. ECO, 1998. (in Russian)

[10] Melnik V., Yakushik I., Lomachynska I., Dragan O. Formation of financial behavior of households in Ukraine. Helvetica, Kherson, 2014. (in Ukrainian)

[11] Zarubina N.N. Economic Sociology. Yurayt Publishing House, 2015. (in Russian)

[12] Kazyuk J., Wenzel V., Gerasymchuk I. In large communities there are more opportunities: experts analyzed the budgets of 665 OTH for 2018. Available at: https://decentralization.gov.ua/news/10649(in Ukrainian)

[13] Melnyk V., Kriuchkov, N., Shchur R. Peculiarities of forming total revenues of united territorial communities in Ukraine under current conditions of transforming the system of public finances. Financial and Credit activity-problems of theory and practice, 2 (33) 2020, 215-222. doi: doi.org/10.18371/.v2i33.2983 (in Ukrainian)

[14] Borshch H.A., Vakulenko V.M., Hrynchuk N.M., Dekhtiarenko Yu.F., Ihnatenko O.S., Kuibida V.S., Tkachuk A.F., Yuzefovych V.V. Resource provision of amalgamated territorial community and its marketing. Instytut hromadianskoho suspilstva, Kyiv, 2017. (in Ukrainian)

[15] Shchur R.I. Finance of Amalgamated Territorial Communities During the Decentralization in Ukraine. Monograph. Osavtsa Yu.V., Ternopil, 2019. (in Ukrainian)

[16] Storonyanska I.Z. Prospects and risks of strengthening the financial capacity of territorial communities in the context of administrative-territorial reform in Ukraine. Economic Journal, XXI (11-12) (2016), 8488. (in Ukrainian)

[17] Shchur R.I. Estimation of financial capacity of the united territorial communities in decentralization conditions. Modern Science-Moderni Veda, 5 (2018). Praha, Ceska Republika, 69-75. 
Address: Viktor Melnyk, Kyiv National Economic University named after Vadym Hetman, 54/1 Prospect Peremogy, Kyiv, 03057 Ukraine;

Roman Shchur, Oksana Tsiupa, Vasyl Stefanyk Precarpathian National University, 57 Shevchenko St., Ivano-Frankivsk, 76018 Ukraine.

E-mail: melnik_viktor@ukr.net; roman.shchur@pnu.edu.ua; oksana09may@gmail.com

Received: September 28, 2020; revised: November 5, 2020.

Мельник Віктор, Щур Роман, Цюпа Оксана. Фінансова поведінка об'єднаних територіальних громад в умовах реформи децентралізації в Україні. Журнал Прикарпатського університету імені Василя Стефаника, 7 (3) (2020), 68-77.

Статтю присвячено дослідженню особливостей функціонування об'єднаних територіальних громад в умовах децентралізації в Україні. Обгрунтовано поняття фінансової поведінки територіальних громад як основи прийняття ефективних управлінських та фінансових рішень, досліджено іï особливості та моделі. Дослідження моделей та особливостей фінансової поведінки об'єднаних територіальних громад дає мождивість оцінити та спрогнозувати вектори їх соціальноекономічного розвитку, встановити причини дотаційності та мождивості підвищення фінансової спроможності щодо формування власних видатків та здійснення тих функцій і завдань, які на них покдадені. Резудьтати дослідження підкреслили необхідність подальших наукових розвідок поведінкових аспектів формування фінансових ресурсів об'єднаних територіальних громад $\mathrm{i}$ обгрунтування їхніх фінансових рішень 3 метою залучення додаткових доходів. Реформа децентралізації в Україні активно почала впроваджуватися тільки починаючи з 2014 року шляхом створення об'єднаних територіальних громад. Автори дослідили сутність фінансової поведінки об'єднаної територіальної громади, що є основою для формування іiі фінансової спроможності, стійкості та соціально-економічного розвитку. В резудьтаті дослідження встановлено, що головним чинником, що впливає на фінансову поведінку об'єднаних територіальних громад в Україні в частині пріоритетності їх бюджетних видатків та інвестиційної діядьності, $€$ масштаб громади (який характеризується показниками площі та чисельності населення). Також авторами доведено, що ключовими мотивами фінансової поведінки об'єднаних територіальних громад у питаннях пріоритетності бюджетних видатків та інвестиційної діяльності є наступні: збільшення власних доходів, підвищення фінансової незалежності органів місцевого самоврядування, що у свою чергу актуалізуе пошук власних шляхів зміцнення фінансового потенціалу та підготовку привабливих пропозицій інвесторам та збільшення кількості робочих місць, а також подальше об'єднання дрібних територіальних громад.

Кдючові слова: бюджетна децентралізація, об'єднана територіальна громада, фінансова поведінка об’єднаної територіальної громади, власні доходи, рівень дотаційності. 